\title{
Hollow-Structured Carbon-Supported Nickel Cobaltite Nanoparticles as an Efficient Bifunctional Electrocatalyst for the Oxygen Reduction and Evolution Reactions
}

\author{
Jie Wang, ${ }^{[\mathrm{a}]}$ Zexing Wu, ${ }^{[\mathrm{a}]}$ Lili Han, ${ }^{[\mathrm{b}, \mathrm{c}]}$ Ruoqian Lin, ${ }^{[\mathrm{b}, \mathrm{d}]}$ Huolin L. Xin, ${ }^{[\mathrm{b}, \mathrm{d}]}$ and Deli Wang*[a]
}

\begin{abstract}
Exploring efficient electrocatalysts for both oxygen reduction reaction (ORR) and oxygen evolution reaction (OER) is essential for fuel cells and metal-air batteries. In this paper, we developed 3D-hollow structured $\mathrm{NiCo}_{2} \mathrm{O}_{4} / \mathrm{C}$ nanoparticles with interconnected pores as bifunctional electrocatalysts which are transformed from solid $\mathrm{NiCo}_{2}$ alloy nanoparticles based on Kirkendall effect. The unique hollow structure of $\mathrm{NiCo}_{2} \mathrm{O}_{4}$ nanoparticles increase the active sites and improve the contact with electrolyte, resulting in excellent ORR and OER performance. In addition, the hollow structured $\mathrm{NiCo}_{2} \mathrm{O}_{4} / \mathrm{C}$ nanoparticles exhibit superior long-term stability for both ORR and OER to commercial Pt/C. The template-free and surfactant-free synthesis strategy could be used for low-cost and large-scale synthesis of hollow structured materials, facilitating screening of high efficiency catalysts for energy conversion.
\end{abstract}

\section{Introduction}

The depletion of fossil fuel sources and environment pollution appeal the development of clean and renewable energy. Extensive attention has been focused on metal-air batteries and fuel cells for their excellent energy density as well as environmental friendly merits. ${ }^{[1]}$ For

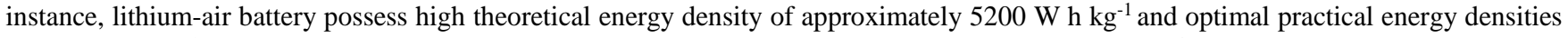
of $1700 \mathrm{~W} \mathrm{~h} \mathrm{~kg}^{-1}$, which outperforms the state-of-art lithium battery and nearly comparable to gasoline. ${ }^{[2]}$ It is really desirable to use these new devices to meet the requirement of the development of society. To make the new device rechargeable, highly efficient bifunctional catalysts for both oxygen reduction reaction (ORR) and oxygen evolution reaction (OER) are really desirable to lower the overpotential so that promote the charge and discharge abilities. ${ }^{[3]}$ The reversible interconversion of water to $\mathrm{O}_{2}$ and $\mathrm{O}_{2}$ to water reactions make it possible for a reversible green energy conversion and storage device to harness energy. ${ }^{[4]}$ However, one of the challenges is the sluggish kinetics of the ORR in the cathode and the OER process in the anode for lithium-air batteries, ${ }^{[3,5]}$ which are the key steps to govern the charge and discharge process and the quality for metal-air batteries. Platinum-based catalysts have been widely recognized as the best catalytic materials for both ORR and OER. ${ }^{[6]}$ Nevertheless, the large scale production of Pt-based catalysts are restricted for its price, scarcity and cycling stability. ${ }^{[7]}$ Moreover, platinum based materials are sensitive to methanol, carbon monoxide or other low molecular weight organics. ${ }^{[8]}$ In addition, large overpotential lowered the energy efficiency of metal-air battery and fuel cells. ${ }^{[9]}$ Therefore, it is of vital important to develop alternative cost-effective bifunctional materials for both excellent ORR and OER activity to lower the electrochemical reaction overpotential. ${ }^{[10]}$

Recently, $3 d$-transition metal based materials (e.g., $\mathrm{Co}, \mathrm{Ni}, \mathrm{Fe}$ and $\mathrm{Mn}$ ) have attracted much attention and recognized as promising alternative catalytic materials applied in energy storage and conversion devices ${ }^{[11]}$ because of their superior merits, such as low cost, high durability, and barely aggregation during runtime in oxidation state in contrast to platinum or palladium-based noble metal nanomaterials. In particular, the excellent ORR and OER catalytic performance reavealed that the $3 d$-transition metal based materials would be optimal materials for metal-air batteries and fuel cells. ${ }^{[10 \mathrm{e}]} \mathrm{Ni}$ based catalysts have been investigated as excellent OER catalysts in recent years. ${ }^{[12]}$ Besides, Co based materials are mostly investigated as high performance ORR catalyst in alkaline media. ${ }^{[13]}$ It is reported that the mixed valence transition metal oxides could make up the solid-state redox couples, like $\mathrm{A}^{3+} / \mathrm{A}^{2+}$, responsible for their notable catalytic performance. ${ }^{[14]}$ In addition, by introducing hollow structure or porosity in the $3 d$-transition metal based materials, the surface area and active sites for the particles would be enlarged and further enhance the electrochemical performance in the application of metal-air batteries, ${ }^{[15]}$ fuel cells, ${ }^{[16]}$ lithium battery ${ }^{[17]}$ as well as supercapacitors. ${ }^{[18]}$ Traditional synthetic approaches for hollow structured nanoparticles involve templates or surfactants. The tedious shell deposit approach and template removal steps limited the scalable production of such materials. ${ }^{[19]}$ Therefore, it is of great importance to develop a template- and surfactant- free method to produce hollow structured materials with both high ORR and OER performance. Herein, we report the preparation of hollow structured $\mathrm{NiCo}_{2} \mathrm{O}_{4}$ nanoparticles with interconnected pores as bifunctional electrocatalysts for ORR and OER in alkaline media. The hollow

Supporting information for this article is given via a link at the end of the document. 
structure was formed based on Kirkendall effect, ${ }^{[20]}$ with no surfactants or templates used during the whole synthetic process. Electrochemical results indicate that the hollow structured $\mathrm{NiCo}_{2} \mathrm{O}_{4}$ nanoparticles outperformed $\mathrm{Co}_{3} \mathrm{O}_{4} / \mathrm{C}, \mathrm{NiO} / \mathrm{C}$ and $\mathrm{NiCo} / \mathrm{C}$ for the ORR, exhibiting a dominant 4-electron pathway. Moreover, the unique hollow structured $\mathrm{NiCo}_{2} \mathrm{O}_{4}$ nanoparticles exhibit superior OER performance and long-term stability in comparison to commercial Pt/C.

\section{Results and Discussion}

The crystal structure of hollow $\mathrm{NiCo}_{2} \mathrm{O}_{4} / \mathrm{C}$ nanoparticles was characterized by XRD. As shown in Figure 1a, carbon supported $\mathrm{NiCo}_{2}$ alloy was formed by reducing homogeneous mixture of $\mathrm{NiCl}_{2}, \mathrm{CoCl}_{2}$ and Vulcan XC-72 precursor under flowing $\mathrm{H}_{2}$ in a tube furnace at $350{ }^{\circ} \mathrm{C}$. The broad peak at around $25^{\circ}$ is correspond to (002) peak of carbon support. The other three diffraction peaks at $44.5^{\circ}, 51.8^{\circ}, 76.4^{\circ}$ can be well indexed as (111), (200), (220) lattice planes of $\mathrm{NiCo}_{2}$ alloy and slightly shift to the lower angle in contrast to the enlarged (220) diffraction peak of Ni/C from the inset graph of Figure 1a. The shift of XRD peak indicated that cobalt atom entered the crystal lattice of nickel resulted in the lattice expansion of nickel. From the surface segregation energies principle, we can see cobalt atom served as the solute exhibit strong anti-segregation which would result in nickel segregation on the particle surface. ${ }^{[21]}$ The hollow structure could be obtained at a proper oxidation temperature based on Kirkendall effect, for which the diffusion rate of metal atoms to the surface is faster than that of oxygen diffuses to the bulk, leaving voids inside of the particles. ${ }^{[22]}$ The optimal oxidation temperature was chosen from TGA measurement (Figure S1a). It can be seen that the weight percentage gradually increase with temperature, which would be explained by the transformation of metal into metal oxides. When the temperature increased over $400{ }^{\circ} \mathrm{C}$, a sharp weight loss was observed because of the combustion of carbon support.
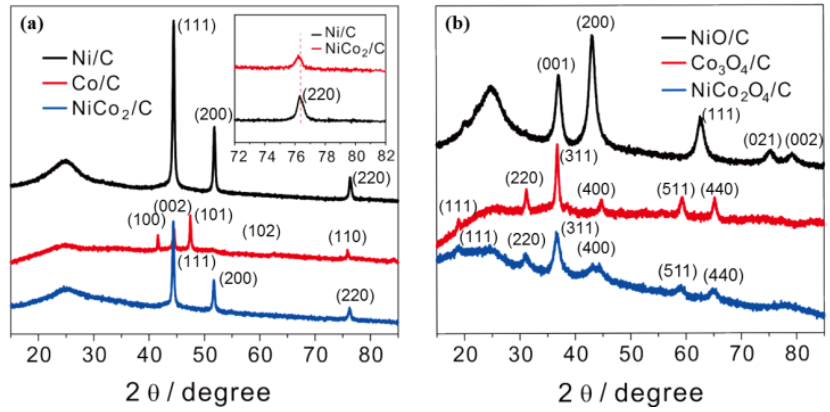

Figure 1. XRD patterns of (a) solid structure $\mathrm{Ni} / \mathrm{C}, \mathrm{Co} / \mathrm{C}, \mathrm{NiCo}_{2} / \mathrm{C}$ nanoparticles and its subsequent oxidation products of (b) hollow structured $\mathrm{NiO} / \mathrm{C}$, $\mathrm{Co}_{3} \mathrm{O}_{4} / \mathrm{C}, \mathrm{NiCo}_{2} \mathrm{O}_{4} / \mathrm{C}$ nanoparticles.

In terms of the TGA curves, $300^{\circ} \mathrm{C}$ was chosen as the optimal temperature for oxidizing $\mathrm{Ni} / \mathrm{C}, \mathrm{Co} / \mathrm{C}$ and $\mathrm{NiCo} / \mathrm{C}$, while lower or higher temperature would result in incomplete oxidation of the samples or severe mass loss of carbon support, respectively. The atomic percentage of $\mathrm{Ni}$ and $\mathrm{Co}$ in $\mathrm{NiCo}_{2} \mathrm{O}_{4} / \mathrm{C}$ nanoparticles was measured by using X-Ray fluorescence (XRF) to be about $34.05 \%$ and $65.95 \%$, which is approximately $1: 2$ (Figure $\mathrm{S} 2$ ), in consistent with the norminal ratio of $\mathrm{Ni}$ to Co. The successful transformation of metallic Ni, $\mathrm{Co}$ and $\mathrm{NiCo}_{2}$ alloys to oxides was verified by XRD in Figure $1 \mathrm{~b}$. The diffraction peaks at $18.9^{\circ}, 31.2^{\circ}, 36.7^{\circ}, 44.6^{\circ}, 59.1^{\circ}, 64.9^{\circ}$ in the blue line attributed to (111), (220), (311), (400), (511) and (440) lattice planes, in consistent with the standard diffraction pattern of $\mathrm{NiCo}_{2} \mathrm{O}_{4}$ (JCPDS No. 02-4211). In addition, the XRD patterns of $\mathrm{Ni} / \mathrm{C}, \mathrm{Co} / \mathrm{C}$ and their corresponding oxides were also seen in Figure 1. The weight percentage of bimetallic oxides and metal oxides is approximately $28 \mathrm{wt} \%$ from TGA measurement (Figure S1b). 


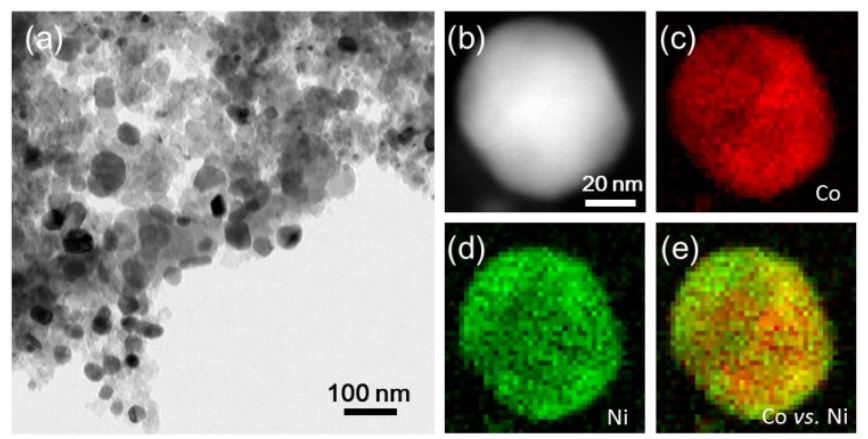

Figure 2. (a-b) BF-STEM and DF-STEM overview of $\mathrm{NiCo}_{2} / \mathrm{C}$ nanoparticles; (c-e) DF-STEM image of one $\mathrm{NiCo}_{2}$ particle and the corresponding EELS elemental mapping of $\mathrm{Co}, \mathrm{Ni}$ and overlay of $\mathrm{Ni}$ and $\mathrm{Co}$.

The microstructure and chemical composition of bimetallic $\mathrm{NiCo}_{2} / \mathrm{C}$ and $\mathrm{NiCo}_{2} \mathrm{O}_{4} / \mathrm{C}$ nanoparticles are characterized by transmission electron microscopy (TEM), bright field scanning transmission electron microscopy (BF-STEM) and dark field scanning transmission electron microscopy (DF-STEM) equipped with electron energy loss spectra (EELS). We can see from Figure 2a that solid structured $\mathrm{NiCo}_{2}$ nanoparticles supported on Vulcan XC-72 are relatively uniform distributed with diameter ranging from $40 \mathrm{~nm}$ to $70 \mathrm{~nm}$. Figure $2 \mathrm{~b}$ shows the DF-STEM image of a $\mathrm{NiCo}_{2}$ alloy particle which is smooth on the surface. Its corresponding EELS elemental distribution is shown in Figure 2(c-e). We can see that the $\mathrm{Co}$ and $\mathrm{Ni}$ atoms are uniformly distributed inside the solid particle but with Ni-rich shell on the surface of the particle which is fully in consistent with the surface segregation energy principle. ${ }^{[21]}$

The $\mathrm{NiCo}_{2}$ alloy was gradually oxidized in a stationary air at $300{ }^{\circ} \mathrm{C}$. Based on the Kirkendall Effect, nickel and cobalt atoms inside of the particles slowly diffused to the surface, while oxygen diffused into the particles. Surface composition of the bimetallic alloy is very sensitive to the external conditions such as in $\mathrm{O}_{2}$ atmosphere which may result in opposite element composition in comparison to the alloy in $\mathrm{H}_{2}$ atmosphere. ${ }^{[23]}$ As the outward diffusion of metal atoms, hollow structure formed after oxidation of the alloy. Figure 3a shows the DF-STEM image of $\mathrm{NiCo}_{2}$ alloy after oxidation. It can be clearly seen that the previous solid $\mathrm{NiCo}_{2}$ alloy particles (Figure 2) transformed to hollow structured $\mathrm{NiCo}_{2} \mathrm{O}_{4}$ nanoparticles with hollow cavities ranging from $20 \mathrm{~nm}$ to $40 \mathrm{~nm}$ and particle size ranging from 40 to $70 \mathrm{~nm}$. In the oxidation process, the inner metal atom for the $\mathrm{NiCo}_{2}$ alloy would gradually move to the outer wall for the combination with oxygen. However, due to the different migration rate between $\mathrm{Ni}$ and $\mathrm{Co}$ atoms as well as the difference in crystal orientation, the location of hollow structure in a nanoparticle would make a difference. As shown in Figure S3a, we can clearly identify the hollow cavity from a nanoparticle which caused by the different contrast due to the extreme transmission intensity under high voltage vacuum condition. The hollow structure was located at different position with interconnected pores. Moreover, we can see interconnected pores more clearly for one $\mathrm{NiCo}_{2} \mathrm{O}_{4}$ particle from the tomographic reconstruction image in Figure S3b. Compared with Figure 2a, we can see that not only the crystal morphology changed, but also the crystal size decreased. The decreasing of crystal size could also be verified from the decreased intensity of diffraction peaks in the XRD patterns (Figure 1b). The inter-planar spacing between adjacent fringes in Figure $3 \mathrm{~b}$ are measured to be $0.46 \mathrm{~nm}$ and $0.24 \mathrm{~nm}$ from high resolution transmission electron microscopy (HRTEM) image of an individual particle (inset of Figure $3 b$ ) corresponding to (111) and (311) planes, respectively. The lattice fringes in HRTEM image are consistent with the theoretical inter-planar spacing from the XRD patterns (Figure 2b). Figure 3c presents a DF-STEM image of a single $\mathrm{NiCo}_{2} \mathrm{O}_{4} \mathrm{nanoparticle}$ depending on the different contrast of outer wall and the interior for the particles, obvious hollow structure with a $20 \mathrm{~nm}$ cavity can be seen. Moreover, in contrast to the solid $\mathrm{NiCo}_{2}$ particle, the original smooth surface was replaced by rough surface after a complete oxidation of $\mathrm{NiCo}_{2}$ alloy. The EELS elemental distribution analysis in Figure 3(d-g) show a cobalt rich shell which is opposite to the solid $\mathrm{NiCo}_{2}$ particle, probably attributed to the higher binding energy of Co-O than that of $\mathrm{Ni}-\mathrm{O},{ }^{[24]}$ causing Co diffused faster than Ni to the particle surface. The formation of hollow structure could provide more active sites by increasing the surface area, facilitating the contact between oxygen and electrolyte. As shown from the nitrogen adsorption-desorption isotherms in Figure S4, the surface area increased from 145.2 $\mathrm{m}^{2} \mathrm{~g}^{-1}$ to $164.1 \mathrm{~m}^{2} \mathrm{~g}^{-1}$ after oxidation of $\mathrm{NiCo}_{2}$ alloy particles. 

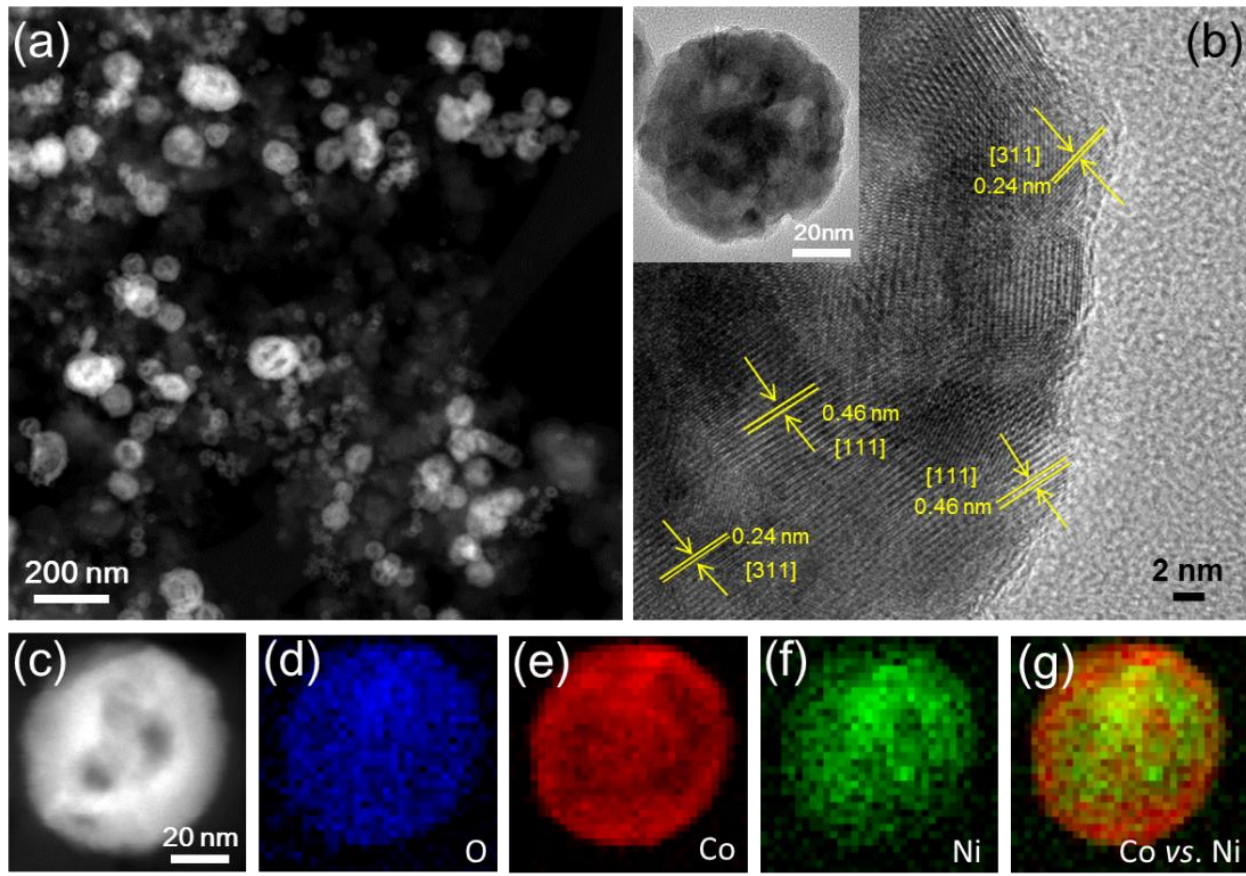

Figure 3. (a) DF-STEM overview of hollow structured $\mathrm{NiCo}_{2} \mathrm{O}_{4} / \mathrm{C}$ nanoparticles; (b) HRTEM image for a hollow structured NiCo $\mathrm{O}_{4}$ particle; (c-g) DFSTEM image of a $\mathrm{NiCo}_{2} \mathrm{O}_{4}$ particle and the corresponding EELS elemental mapping of $\mathrm{Co}, \mathrm{Ni}, \mathrm{O}$ and overlay of $\mathrm{Ni}$ and $\mathrm{Co}$.

The electrocatalytic activities of the materials for ORR were first evaluated by cyclic voltammetry (CV) measurement in $\mathrm{N}_{2}-$ and $\mathrm{O}_{2-}$ saturated $0.1 \mathrm{M} \mathrm{KOH}$ solution at a scan rate of $50 \mathrm{mV} \mathrm{s}^{-1}$ (Figure S5). The CVs comparison of the hollow structured $\mathrm{NiCo}_{2} \mathrm{O}_{4} / \mathrm{C}_{\text {and }}$ alloyed $\mathrm{NiCo}_{2} / \mathrm{C}$ particles in $\mathrm{N}_{2}$-saturated $\mathrm{KOH}$ solution clearly show that the formation of hollow structure boosted the double-layer current, indicating the enlargement of surface area of materials, which agree with the BET measurement in Figure S4. Moreover, the hollow structured $\mathrm{NiCo}_{2} \mathrm{O}_{4} / \mathrm{C}$ shows obvious oxygen reduction peak at around $0.70 \mathrm{~V}$, while the peak is at around $0.67 \mathrm{~V}$ on $\mathrm{NiCo} / \mathrm{C}$ electrode in $\mathrm{O}_{2}$-saturated solution. The oxygen reduction peak is about $30 \mathrm{mV}$ positive, indicating an enhancement of ORR performance on hollow structured $\mathrm{NiCo}_{2} \mathrm{O}_{4} / \mathrm{C}$ hybrid composite.

To gain further insight on the ORR electrocatalytic activity, ORR polarization curves were measured on different catalysts by using a rotating disk electrode (RDE) in $\mathrm{O}_{2}$-saturated $0.1 \mathrm{M} \mathrm{KOH}$ solution at a rotation rate of $1600 \mathrm{rpm}$ and a scan rate of $5 \mathrm{mV} \mathrm{s}{ }^{-1}$. As shown in Figure $4 \mathrm{a}$, the hollow structured $\mathrm{NiCo}_{2} \mathrm{O}_{4} / \mathrm{C}$ nanoparticles exhibit the best electrocatalytic activity for ORR among these non-Pt electrocatalysts, with a half wave potential $\left(E_{1 / 2}\right)$ of $0.71 \mathrm{~V}$ vs. RHE. Although the ORR activity is lower than that on commercial Pt/C $\left(E_{1 / 2}\right.$ is $\left.0.80 \mathrm{~V}\right)$, the cost of this kind of catalysts is much lower than Pt. Apparently, the lower half-wave potential $(0.66 \mathrm{~V})$ and limit current density $\left(4.9 \mathrm{~mA} \mathrm{~cm}^{-2}\right.$, Figure $\left.\mathrm{R} 3\right)$ of $\mathrm{NiCo}_{2} / \mathrm{C}$ indicated the necessity for the formation of hollow structure. It is noteworthy that the lower half wave potential and limit current density of directly oxidized $\mathrm{NiCo}_{2} \mathrm{O}_{4} / \mathrm{C}$ (denoted as D-NiCo $\mathrm{O}_{4} / \mathrm{C}$ ) revealed great advantage for the novel two-step method. In order to investigate the influence of mixed valence for the catalytic performance, we compare the CV curves (Figure S6) of hollow structured $\mathrm{NiCo}_{2} \mathrm{O}_{4} / \mathrm{C}, \mathrm{NiO} / \mathrm{C}$ and $\mathrm{Co}_{3} \mathrm{O}_{4} / \mathrm{C}$ with same mass loading of metal on the electrode (Figure $\mathrm{S} 1$ ) at a potential range from $0.05 \mathrm{~V}-1.4 \mathrm{~V}$ with a scanning rate of $50 \mathrm{mV} \mathrm{s}^{-1}$ in $\mathrm{N}_{2}$-saturated $0.1 \mathrm{M} \mathrm{KOH}$ solution. In comparison to the small redox peaks from region I for hollow structured $\mathrm{Co}_{3} \mathrm{O}_{4} / \mathrm{C}$ and $\mathrm{NiO} / \mathrm{C}$, hollow structured $\mathrm{NiCo}_{2} \mathrm{O}_{4} / \mathrm{C}$ exhibited obvious oxidation peaks at region II and two reduction peaks at regionsIII and IV. Thus, the enhanced electrocatalytic activity of $\mathrm{NiCo}_{2} \mathrm{O}_{4} / \mathrm{C}$ (higher half-wave potential than hollow structured $\mathrm{Co}_{3} \mathrm{O}_{4} / \mathrm{C}$ and $\mathrm{NiO} / \mathrm{C}$ ) is attributed to the changing of redox peaks by the substitute of $\mathrm{Co}$ to $\mathrm{Ni}$. ${ }^{[25]} \mathrm{This}$ result also indicated that $\mathrm{O}_{2}$ is mostly easily reduced on $\mathrm{NiCo}_{2} \mathrm{O}_{4}$ catalyst.

The kinetics of the ORR on hollow structured $\mathrm{NiCo}_{2} \mathrm{O}_{4} / \mathrm{C}$ nanoparticles was further explored on RDE electrode with different rotation rates (Figure 4b). Well defined diffusion limiting current can be clearly obtained. The inset in Figure 4b presents the corresponding Koutecky-Levich plots at various potentials obtained from the inverse of the current density $1 / j$ vs. $\omega^{-1 / 2}$. Three paralleled straight line at three different potentials, indicated the first-order dependence of the kinetics for the ORR on hollow structured $\mathrm{NiCo}_{2} \mathrm{O}_{4} / \mathrm{C}_{\text {nanoparticles}}$, similar to previous literatures. ${ }^{[26]}$ The electrons transfer numbers was calculated to be $3.89,3.92$, and 4.01 at potential of $0.55,0.60,0.65 \mathrm{~V}$, respectively, suggesting a 4-electron ORR pathway for the hollow structured $\mathrm{NiCo}_{2} \mathrm{O}_{4} / \mathrm{C}$ nanoparticles. 
To better understand the mechanism of the ORR reaction pathway and hydrogen peroxide $\left(\mathrm{HO}_{2}^{-}\right)$production, rotating ring-disk electrode (RRDE) measurement was performed on hollow structured $\mathrm{NiCo}_{2} \mathrm{O}_{4} / \mathrm{C}$ nanoparticles. The electron transfer number (n) and $\mathrm{HO}_{2}$ production were calculated via equation (1) and (2) from RRDE voltammogram in the inset of Figure 4c, where the ring potential was set at $1.2 \mathrm{~V}$. As for the two equations, $j_{D}$ and $j_{R}$ present the faradic disk current and the ring current, $\mathrm{N}$ equals to 0.37 represents the collection efficiency. At a rotation rate of $1600 \mathrm{rpm}$, the electron transfer number was calculated to be close to 4 at potential ranging from $0.1 \mathrm{~V}$ to $0.8 \mathrm{~V}$, which is similar to commercial Pt/C (Figure S7). The $\mathrm{HO}_{2}^{-}$yield was calculated to be less than $5 \%$ below $0.8 \mathrm{~V}$, suggesting the ORR process was dominant by a direct 4-electron pathway. The RRDE results on hollow structured $\mathrm{NiCo}_{2} \mathrm{O}_{4} / \mathrm{C}$ are in consistent with the RDE results.

$$
n=\frac{4 j_{D}}{j_{D}+\frac{j_{R}}{N}} \quad H_{2} O_{2} \%=\frac{\frac{2 j_{R}}{N}}{j_{D}+\frac{j_{R}}{N}} \times 100 \%
$$
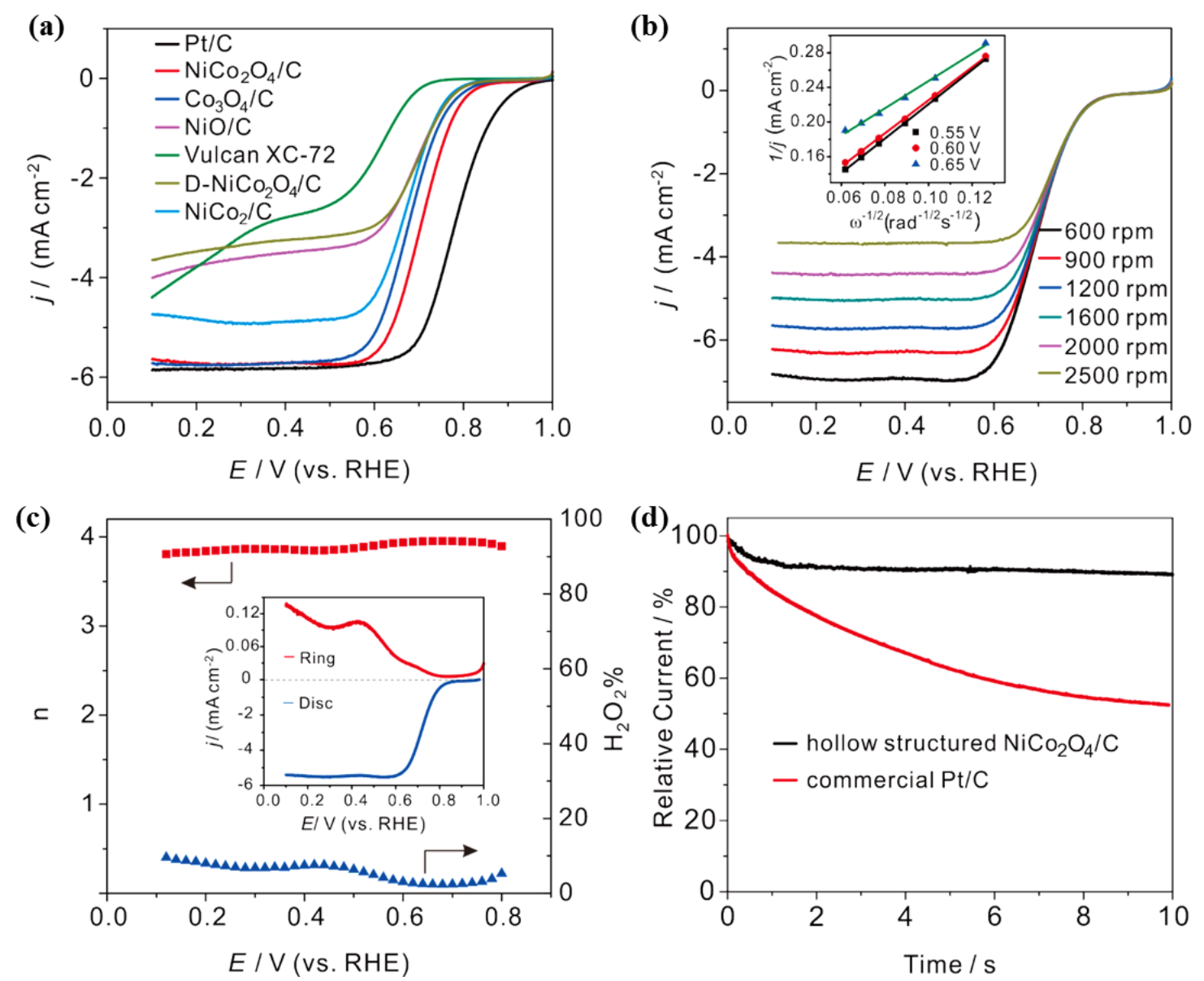

Figure 4. (a) ORR polarization curves on Vulcan XC-72, $\mathrm{NiO} / \mathrm{C}, \mathrm{Co}_{3} \mathrm{O}_{4} / \mathrm{C}, \mathrm{NiCo}_{2} / \mathrm{C}, \mathrm{D}-\mathrm{NiCo}_{2} \mathrm{O}_{4} / \mathrm{C}, \mathrm{NiCo}_{2} \mathrm{O}_{4} / \mathrm{C}$ and $\mathrm{Pt} / \mathrm{C}$ in $\mathrm{O}_{2}$-saturated $0.1 \mathrm{M} \mathrm{KOH}$ solution at scan rate of $5 \mathrm{mV} \mathrm{s}^{-1}$ and rotation rate of $1600 \mathrm{rpm}$; (b) ORR polarization curves of $\mathrm{NiCo}_{2} \mathrm{O}_{4} / \mathrm{C}$ in $\mathrm{O}_{2}$-saturated $0.1 \mathrm{M} \mathrm{KOH}$ solution at different rotation rates and the corresponding Koutecky-Levich plots of $\mathrm{NiCo}_{2} \mathrm{O}_{4} / \mathrm{MWCNT}$ at potentials of $0.55 \mathrm{~V}, 0.6 \mathrm{~V}$ and $0.65 \mathrm{~V}$ (inset); (c) The electron-transfer number $\mathrm{n}, \mathrm{H}_{2} \mathrm{O}_{2}$ yield and $\mathrm{RRDE}$ voltammograms (inset) on hollow structured $\mathrm{NiCo}_{2} \mathrm{O}_{4} / \mathrm{C}$; (d) i-t chronoamperometric stability measurement (at a constant potential of $0.6 \mathrm{~V}$ ) on $\mathrm{NiCO}_{2} \mathrm{O}_{4} / \mathrm{C}$ and $\mathrm{Pt} / \mathrm{C}$ in $\mathrm{O}_{2}$-saturated $0.1 \mathrm{M} \mathrm{KOH}$ solution.

The stability performance for the electrode reaction is an integral part of considerations for the practical application of metal-air batteries and fuel cells. The durability of the hollow structured $\mathrm{NiCo} 2 \mathrm{O} 4 / \mathrm{C}$ catalyst was measured using chronoamperometry method in comparison to commercial $\mathrm{Pt} / \mathrm{C}$, which was performed at a constant potential of $0.6 \mathrm{~V}$ for $10 \mathrm{~h}$ in $\mathrm{O}_{2}$-saturated $0.1 \mathrm{M} \mathrm{KOH}$ solution (Figure $4 \mathrm{~d}$ ). Remarkably, the corresponding current-time curve of hollow structured $\mathrm{NiCo}_{2} \mathrm{O}_{4} / \mathrm{C}$ nanoparticles exhibits negligible current decay $(\sim 9 \%)$. In contrast, $\mathrm{Pt} / \mathrm{C}$ suffers from a gradually decrease of current, with a current maintain of about $52 \%$ after $10 \mathrm{~h}$. The durability results clearly indicate that the hollow structured $\mathrm{NiCo}_{2} \mathrm{O}_{4} / \mathrm{C}$ nanoparticles exhibit superior long term stability for the ORR relative to Pt/C catalysts which is particularly desirable for metal-air batteries and fuel cells.

The oxygen evolution reaction (OER) catalytic performance of the hollow structured $\mathrm{NiCo}_{2} \mathrm{O}_{4} / \mathrm{C}$ was investigated in $\mathrm{N}_{2}-$ saturated $0.1 \mathrm{M}$ $\mathrm{KOH}$ solution at a potential range from $0.9 \mathrm{~V}$ to $1.8 \mathrm{~V}$ with a rotation rate of $1600 \mathrm{rpm}$. As shown in Figure 5a, the hollow structured $\mathrm{NiCO}_{2} \mathrm{O}_{4} / \mathrm{C}$ shows a high activity for OER, with the lowest onset potential of $1.25 \mathrm{~V}$ than other samples $(1.35 \mathrm{~V}$ for $\mathrm{NiO} / \mathrm{C}$, $1.30 \mathrm{~V}$ for $\mathrm{NiCo}_{2} / \mathrm{C}, 1.45 \mathrm{~V}$ for $\mathrm{Co}_{3} \mathrm{O}_{4} / \mathrm{C}$ and $1.55 \mathrm{~V}$ for $\mathrm{Pt} / \mathrm{C}$ ). The OER current density on hollow structured $\mathrm{NiCo}_{2} \mathrm{O}_{4} / \mathrm{C}$ is $25.6 \mathrm{~mA} \mathrm{~cm}{ }^{-2}$ at $1.8 \mathrm{~V}$, 
which is outperformed $\mathrm{Co}_{3} \mathrm{O}_{4} / \mathrm{C}\left(\sim 15.8 \mathrm{~mA} \mathrm{~cm}^{-2}\right), \mathrm{NiCo}_{2} / \mathrm{C}\left(\sim 18.4 \mathrm{~mA} \mathrm{~cm}^{-2}\right)$ and commercial $\mathrm{Pt} / \mathrm{C}\left(\sim 3.1 \mathrm{~mA} \mathrm{~cm}{ }^{-2}\right)$, and close to NiO/C $\left.(26.1 \mathrm{~mA} \mathrm{~cm})^{-2}\right)$. The potential required at current density of $10 \mathrm{~mA} \mathrm{~cm}{ }^{-2}\left(E_{j=10 \mathrm{mAcm}-2}\right)$ represents a $10 \%$ efficient solar water-splitting device, ${ }^{[13 b, 27]}$ which is commonly used to judge the OER activity. As for the hollow structured $\mathrm{NiCo}_{2} \mathrm{O}_{4} / \mathrm{C}, E_{j=10} \mathrm{mAcm}-2$ is about $1.67 \mathrm{~V}$, which is much less positive than that of $\mathrm{Pt} / \mathrm{C}(1.86 \mathrm{~V}$, Figure $5 \mathrm{~b})$, indicating the hollow structured $\mathrm{NiCo}_{2} \mathrm{O}_{4} / \mathrm{C}$ gives rise to a $10 \mathrm{~mA} \mathrm{~cm}{ }^{-2}$ at small overpotential of $0.44 \mathrm{~V}$. Despite that Pt exhibits higher ORR activity than hollow structured $\mathrm{NiCo}_{2} \mathrm{O}_{4} / \mathrm{C}$ (Figure $4 \mathrm{a}, E_{1 / 2}$ is $90 \mathrm{mV}$ more positive), the OER activity is much worse $\left(E_{j=10 \mathrm{mAcm}-2}\right.$ is about $190 \mathrm{mV}$ positive). It is worth noting that $\mathrm{NiO} / \mathrm{C}$ exhibited a slightly better OER activity than $\mathrm{NiCo}_{2} \mathrm{O}_{4} / \mathrm{C}\left(E_{j=10 \mathrm{mAcm}-2}\right.$ is only about $4 \mathrm{mV}$ negative), the ORR activity on $\mathrm{NiO} / \mathrm{C}$ is much inferior to that of hollow structured $\mathrm{NiCo}_{2} \mathrm{O}_{4} / \mathrm{C}$ (Figure 2a). The difference in potential between $E_{j=10 \mathrm{mAcm}-2}$ and $E_{1 / 2}$ is usually used to evaluated the bifunctional catalytic activity of materials. ${ }^{[13 b]} \mathrm{A}$ small potential difference means better bifunctional catalytic activity. The value is about $960 \mathrm{mV}$ for hollow structured $\mathrm{NiCo}_{2} \mathrm{O}_{4} / \mathrm{C}$, while it is $1060 \mathrm{mV}$ for $\mathrm{Pt} / \mathrm{C}$.

The Tafel plots for OER on different electrodes were performed to further investigate the electrode kinetic. As shown in Figure 5c, the Tafel slope on hollow structured $\mathrm{NiCo}_{2} \mathrm{O}_{4} / \mathrm{C}$ is $\sim 78.7 \mathrm{mV} \mathrm{dec}^{-1}$, which is much lower than that of $\mathrm{NiCo}_{2} / \mathrm{C}\left(\sim 169.9 \mathrm{mV} \mathrm{dec}^{-1}\right), \mathrm{Co}_{3} \mathrm{O}_{4} / \mathrm{C}$ $\left(\sim 187.6 \mathrm{mV} \mathrm{dec}^{-1}\right)$ and $\mathrm{Pt} / \mathrm{C}\left(\sim 130.2 \mathrm{mV} \mathrm{dec}^{-1}\right)$, indicating a more favorable OER kinetic on hollow structured $\mathrm{NiCo}_{2} \mathrm{O}_{4} / \mathrm{C}$. The hollow structured $\mathrm{NiCo}_{2} \mathrm{O}_{4} / \mathrm{C}$ exhibits not only superior bifunctional electrocatalytic activity, but also long-term stability. As shown in Figure $5 \mathrm{~d}$, the hollow structured $\mathrm{NiCo}_{2} \mathrm{O}_{4} / \mathrm{C}$ exhibited excellent durability, with no current decay during 2000 continuous potential cycles. In comparison, $\mathrm{Pt} / \mathrm{C}$ suffers from severe current decay and almost no catalytic activity remaining. Also, the chronopotentiometry test indicated that the hollow structured $\mathrm{NiCo}_{2} \mathrm{O}_{4} / \mathrm{C}$ exhibited excellent potential stability at a constant current density of $10 \mathrm{~mA} \mathrm{~cm}^{-2}$ for 13000 seconds. While for $\mathrm{Pt} / \mathrm{C}$, there is a rapid potential increasing after only $700 \mathrm{~s}$ (Figure S8). The excellent electrocatalytic activity and durability suggest that hollow structured $\mathrm{NiCO}_{2} \mathrm{O}_{4} / \mathrm{C}$ nanoparticles are promising bifunctional electrocatalyst for both ORR and OER.
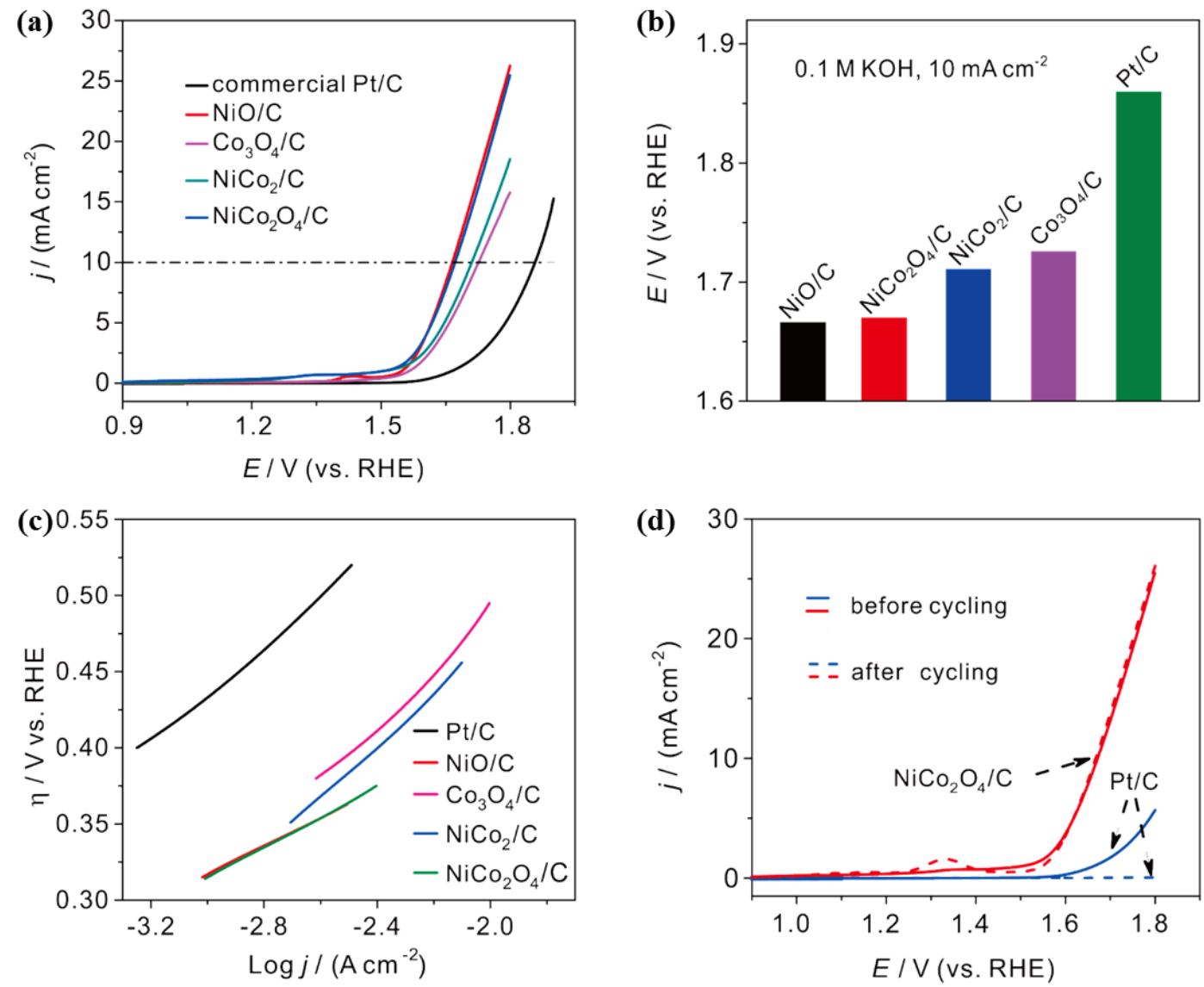

Figure 5. (a) OER polarization curves on $\mathrm{NiO} / \mathrm{C}, \mathrm{Co}_{3} \mathrm{O}_{4} / \mathrm{C}, \mathrm{NiCo}_{2} / \mathrm{C}, \mathrm{NiCo}_{2} \mathrm{O}_{4} / \mathrm{C}$ and $\mathrm{Pt} / \mathrm{C}$ measured in $\mathrm{N}_{2}$-saturated $0.1 \mathrm{M} \mathrm{KOH}$ solution at a rotation rate of $1600 \mathrm{rpm}$; (b) Potential comparison on different electrodes at $10 \mathrm{~mA} \mathrm{~cm}-2$ from the polarization curves in (a); (c) Tafel plots of $\mathrm{NiO} / \mathrm{C}, \mathrm{Co}_{3} \mathrm{O}_{4} / \mathrm{C}, \mathrm{NiCo} / \mathrm{C}$, $\mathrm{NiCo}_{2} \mathrm{O}_{4} / \mathrm{C}$ and Pt/C recorded in $\mathrm{N}_{2}$-saturated $0.1 \mathrm{M} \mathrm{KOH}$ solution; (d) OER polarization curves of $\mathrm{NiCo}_{2} \mathrm{O}_{4} / \mathrm{C}$ and Pt/C before and after 2000 cycles in $\mathrm{N}_{2}^{-}$ saturated 


\section{Conclusions}

In conclusion, the carbon supported hollow structured $\mathrm{NiCo}_{2} \mathrm{O}_{4}$ nanoparticles have been successfully prepared via a facile two-step method. The preparation procedure is simple, template- and surfactant- free, which is suitable for scalable production. The hollow structured hybrid showed much better electrocatalytic activity for both ORR and OER in comparison to single-metal oxides. $\mathrm{Moreover}$ the $\mathrm{NiCo}_{2} \mathrm{O}_{4} / \mathrm{C}$ exhibits excellent durability for ORR and OER relative to Pt in alkaline solution. The reported synthesis provides a simple and costeffective method for preparing hollow structured bimetallic oxide nanoparticles, offering a general approach for a promising new class of non-precious metal catalysts for metal-air batteries.

\section{Experimental Section}

Sample preparation. A "one-pot, two-step" strategy was developed to synthesize hollow structured $\mathrm{NiCo}_{2} \mathrm{O}_{4}$ nanoparticles supported on carbon ${ }^{[16 b, 28]}$ $\mathrm{NiCO}_{2}$ alloy nanoparticles were first synthesized via an impregnation-reduction method, and then oxidized in air to form hollow structured oxides based on Kirkendall effect ${ }^{[22]}$. In detail, $108 \mathrm{mg} \mathrm{CoCl}_{2} \cdot 6 \mathrm{H}_{2} \mathrm{O}, 54 \mathrm{mg}$ of $\mathrm{NiCl}_{2} \cdot 6 \mathrm{H}_{2} \mathrm{O}$ and $160 \mathrm{mg}$ of Vulcan XC-72 were added into a $25 \mathrm{~mL}$ of baker. Then, $10 \mathrm{~mL}$ of purified water was poured into the baker followed by exchanging magnetic stirring and ultrasonic dispersion at $60{ }^{\circ} \mathrm{C}$ until the solution was evaporated to form thick slurry. The composite was then placed in a vacuum drying oven at $40{ }^{\circ} \mathrm{C}$ overnight and ensure sufficient drying. After the process of milling in agate mortar, the resulting powder was annealed in $350{ }^{\circ} \mathrm{C}$ for $3 \mathrm{~h}$ under $\mathrm{H}_{2}$ atmosphere. The pre-prepared samples were then calcined in air at a heating rate of $1{ }^{\circ} \mathrm{C} \mathrm{min}-1$ from room temperature to $300{ }^{\circ} \mathrm{C}$ and maintain for $10 \mathrm{~h}$ to obtain the final product. In comparison, $\mathrm{Co}_{3} \mathrm{O}_{4} / \mathrm{C}$ and NiO/C nanoparticles were synthesized under the same condition with a metal loading of $20 \mathrm{wt} \%$.

The directly oxidized $\mathrm{NiCo}_{2} \mathrm{O}_{4} / \mathrm{C}$ (denoted as $\mathrm{D}-\mathrm{NiCo}_{2} \mathrm{O}_{4} / \mathrm{C}$ ) was obtained by directly oxidation of the mixed $\mathrm{NiCl}_{2}, \mathrm{CoCl}_{2}$ and $\mathrm{Vulcan} \mathrm{XC}-72$ precursor.

Physical characterization. Powder X-ray diffraction (XRD) was performed by using an X'Pert PRO diffractometer, and diffraction patterns were collected at a scanning rate of $4 \% \mathrm{~min}$. Thermal gravimetric analysis (TGA) was conducted on TA-Q500 Instrument at a heating rate of $5{ }^{\circ} \mathrm{C} / \mathrm{min}$. X-Ray Fluorescence (XRF) was collected on EAGLE III, EDAX Inc. STEM tomographic images were obtained using 200 and $300 \mathrm{keV}$ field-emission S/TEMs. Electron Energy Loss Spectroscopy (EELS) data were acquired using a Gatan Tridiem spectrometer.

Electrochemical measurements. All the electrochemical measurements were performed at room temperature (298 K) by using rotating disc electrode (RDE) and rotating ring-disc electrode (RRDE) with $5 \mathrm{~mm}$-diameter glassy carbon substrate as working electrode. Carbon paper was used as counter electrode to eliminate the contamination from conventional Pt electrode, and reverse hydrogen electrode (RHE, $E^{\theta}=-0.768 \mathrm{~V}$ vs. SHE) was served as reference electrode in $0.1 \mathrm{M} \mathrm{KOH}$ solution. $5 \mathrm{mg}$ of samples was dispersed in $1 \mathrm{~mL}$ isopropanol/Nafion hybrid solutions and ultrasonic dispersed to form homogeneous ink. $7.8 \mathrm{uL}$ of ink (9.9 uL for RRDE) was dropped onto the glassy carbon substrate, and dried naturally. The loading quantity of commercial $\mathrm{Pt} / \mathrm{C}$ is about $15 \mathrm{ug} \mathrm{cm}^{-2}$. The RDE and RRDE performance of the samples are operated in $\mathrm{O}_{2}$-saturated $0.1 \mathrm{M} \mathrm{KOH}$ solution at a sweep rate of $5 \mathrm{mV} \mathrm{s}^{-1}$.

\section{Acknowledgements}

This work was supported by the National Natural Science Foundation (21306060), the Program for New Century Excellent Talents in Universities of China (NCET-13-0237), the Fundamental Research Funds for the Central University (2013TS136). We thank Analytical and Testing Center of Huazhong University of Science \& Technology for allowing us to use its facilities. S/TEM and EELS work was carried out at the Center for Functional Nanomaterials, Brookhaven National Laboratory, which is supported by the U.S. Department of Energy, Office of Basic Energy Sciences, under Contract No. DE-AC02-98CH10886.

Keywords: hollow structure $\bullet \mathrm{NiCo}_{2} \mathrm{O}_{4} / \mathrm{C} \bullet$ electrocatalyst $\bullet$ oxygen reduction reaction $\bullet$ oxygen evolution reaction

[1] C. Liu, F. Li, L. P. Ma, H. M. Cheng, Adv. Mater. 2010, 22, E28-E62.

[2] a) J.-S. Lee, S. Tai Kim, R. Cao, N.-S. Choi, M. Liu, K. T. Lee, J. Cho, Adv. Energy Mater. 2011, 1, 34-50; b) Z. Chen, A. Yu, D. Higgins, H. Li, H. Wang, Z. Chen, Nano Lett. 2012, 12, 1946-1952.

[3] Z.-L. Wang, D. Xu, J.-J. Xu, X.-B. Zhang, Chem. Soc. Rev. 2014, 43, 7746-7786.

[4] M. Prabu, K. Ketpang, S. Shanmugam, Nanoscale 2014, 6, 3173-3181. 
[5] D. Wang, H. L. Xin, R. Hovden, H. Wang, Y. Yu, D. A. Muller, F. J. DiSalvo, H. D. Abruña, Nat. Mater. $2013,12,81-87$.

[6] a) B. Lim, M. Jiang, P. H. C. Camargo, E. C. Cho, J. Tao, X. Lu, Y. Zhu, Y. Xia, Science 2009, 324, 1302-1305; b) B. Y. Xia, W. T. Ng, H. B. Wu, X. Wang, X. W. Lou, Angew. Chem. Int. Ed. 2012, 51, 7213-7216; c) D. Higgins, M. A. Hoque, M. H. Seo, R. Wang, F. Hassan, J. Y. Choi, M. Pritzker, A. Yu, J. Zhang, Z. Chen, Adv. Funct. Mater. 2014, 24, 4324-4324.

[7] a) M. K. Debe, Nature 2012, 486, 43-51; b) S.-E. Jang, H. Kim, J. Am. Chem. Soc. 2010, 132, 14700-14701; c) J. P. Meyers, R. M. Darling, J. Electrochem. Soc. 2006, 153, A1432-A1442; d) J. Wang, H. L. Xin, D. Wang, Part. Part. Syst. Charact. 2014, 31, 515-539.

[8] a) T. Y. Ma, Y. Zheng, S. Dai, M. Jaroniec, S. Z. Qiao, J. Mater. Chem. A 2014, 2, 8676-862; b) J. Jin, F. Pan, L. Jiang, X. Fu, A. Liang, Z. Wei, J. Zhang, G. Sun, ACS Nano 2014, 8, 3313-3321.

[9] a) P. G. Bruce, L. J. Hardwick, K. M. Abraham, MRS Bull. 2011, 36, 506-512; b) C.-F. Chen, G. King, R. M. Dickerson, P. A. Papin, S. Gupta, W. R. Kellogg, G. Wu, Nano Energy 2015, 13, 423-432..

[10] a) Y. Zheng, Y. Jiao, J. Chen, J. Liu, J. Liang, A. Du, W. Zhang, Z. Zhu, S. C. Smith, M. Jaroniec, G. Q. Lu, S. Z. Qiao, J. Am. Chem. Soc. 2011, 133, 20116-20119; b) S. Guo, S. Zhang, S. Sun, Angew. Chem. Int. Ed.2013, 52, 8526-8544; c) G. Zhang, C. Li, J. Liu, L. Zhou, R. Liu, X. Han, H. Huang, H. Hu, Y. Liu, Z. Kang, J. Mater. Chem. A 2014, 2, 8184-8189; d) Q. Liu, J. Jin, J. Zhang, ACS Appl. Mater. Interfaces 2013, 5, 5002-5008; e) H. W. Park, D. U. Lee, P. Zamani, M. H. Seo, L. F. Nazar, Z. Chen, Nano Energy 2014, 10, 192-200.

[11] a) J. Zhang, C. Guo, L. Zhang, C. M. Li, Chem. Commun. 2013, 49, 6334-6336; b) Y. Gorlin, T. F. Jaramillo, J. Am. Chem. Soc. 2010, 132, 1361213614; c) L.-B. Zhang, S.-R. Yang, J.-Q. Wang, Y. Xu, X.-Z. Kong, Chinese Chem. Lett. 2015, 26, 522-528.

[12] a) Q. Liu, J. Jin, J. Zhang, ACS Appl. Mater. Inter., 2013, 5, 5002-5008; b) I. Godwin, M. Lyons, Electrochem. Commun., $2013,32,39-42$.

[13] a)J. Xu, P. Gao, T. S. Zhao, Energy Environ. Sci., 2012, 5, 5333-5339; b)J. Xiao, Q. Kuang, S. Yang, F. Xiao, S. Wang, L. Guo, Sci. Rep., 2013, 3, 2300-2307.

[14] a) D. U. Lee, B. J. Kim, Z. Chen, J. Mater. Chem. A 2013, 1, 4754-4762; b) H. Zhu, S. Zhang, Y. X. Huang, L. Wu, S. Sun, Nano Lett. 2013, 13, 2947-2951.

[15] a) S. Ganapathy, B. D. Adams, G. Stenou, M. S. Anastasaki, K. Goubitz, X. F. Miao, L. F. Nazar, M. Wagemaker, J. Am. Chem. Soc. 2014, 136, 16335-16344; b) B. J. Bergner, A. Schurmann, K. Peppler, A. Garsuch, J. Janek, J. Am. Chem. Soc. 2014, 136, 15054-15064; c) J. Lu, L. Cheng, K. C. Lau, E. Tyo, X. Luo, J. Wen, D. Miller, R. S. Assary, H. H. Wang, P. Redfern, H. Wu, J. B. Park, Y. K. Sun, S. Vajda, K. Amine, L. A. Curtiss, Nat. Commun. 2014, 5, 4895-4902.

[16] a) C. Cui, L. Gan, M. Heggen, S. Rudi, P. Strasser, Nat. Mater. 2013, 12, 765-771; b) J. Wang, H. L. Xin, J. Zhu, S. Liu, Z. Wu, D. Wang, J. Mater Chem. A 2015, 3, 1601-1608.

[17] a) X. W. Lou, Y. Wang, C. Yuan, J. Y. Lee, L. A. Archer, Adv. Mater. 2006, 18, 2325-2329; b) A. Pan, H. B. Wu, L. Yu, X. W. D. Lou, Angew. Chem. 2013, 125, 2282-2286.

[18] a) X. Lai, J. E. Halpert, D. Wang, Energy Environ. Science 2012, 5, 5604-5618; b) P. Wang, Y. Xu, H. Liu, Y. Chen, J. Yang, Q. Tan, Nano Energy 2015, 15, 116-124.

[19] A. Vu, Y. Qian, A. Stein, Adv. Energy Mater. 2012, 2, 1056-1085.

[20] a) H. J. Fan, U. Gösele, M. Zacharias, Small 2007, 3, 1660-1671; b) W. Wang, M. Dahl, Y. Yin, Chem. Mater. 2012, 25, 1179-1189.

[21] A. Ruban, H. L. Skriver, J. K. Nørskov, Phys. Rev. B 1999, 59, 15990-16000.

[22] Y. Yin, R. M. Rioux, C. K. Erdonmez, S. Hughes, G. A. Somorjai, A. P. Alivisatos, Science 2004, 304, $711-714$

[23] D. D. Beck, C. L. DiMaggio, G. B. Fisher, Surf. Sci. 1993, 297, 293-302.

[24] C. Zhu, D. Wen, S. Leubner, M. Oschatz, W. Liu, M. Holzschuh, F. Simon, S. Kaskel, A. Eychmueller, Chem. Commun. $2015,51,7851-7854$.

[25] a) H. Zhu, S. Zhang, Y.-X. Huang, L. Wu, S. Sun, Nano lett., 2013, 13, 2947-2951; b) Y. Liang, H. Wang, P. Diao, W. Chang, G. Hong, Y. Li, M. Gong, L. M. Xie, J. G. Zhou, J. Wang, T. Z. Regier, F. Wei, H. J. Dai, J. Am. Chem. Soc., 2012, 134, 15849-15857.

[26] a) S. S. Kim, Y. R. Kim, T. D. Chung, B. H. Sohn, Adv. Funct. Mater. 2014, 24, 2764-2771; b) W. Niu, L. Li, X. Liu, N. Wang, J. Liu, W. Zhou, Z. Tang, S. Chen, J. Am. Chem. Soc. 2015, 137, 5555-5562.

[27] a) M. G. Walter, E. L. Warren, J. R. McKone, S. W. Boettcher, Q. Mi, E. A. Santori, N. S. Lewis, Chem. Rev. 2010, 110, 6446-6473; b) M. F. Weber, M. J. Dignam, J. Electrochem. Soc. 1984, 131, 1258-1265; c) C. C. McCrory, S. Jung, J. C. Peters, T. F. Jaramillo, J. Am. Chem. Soc. 2013, 135, 16977-16987.

[28] D. L. Wang, Y. C. Yu, H. He, J. Wang, W. D. Zhou, H. D. Abruna, ACS Nano 2015, 9, 1775-1781. 